\title{
Cold-pressed rapeseed cake or full fat rapeseed to organic dairy cows - milk production and profitability
}

\author{
Birgitta Johansson • Karl-Ivar Kumm • \\ Maria Åkerlind • Elisabet Nadeau
}

Received: 26 June 2014 / Accepted: 21 December 2014 / Published online: 17 January 2015

(C) The Author(s) 2015. This article is published with open access at Springerlink.com

\begin{abstract}
The interest in growing and feeding locally produced feeds is increasing. Case studies in Sweden have shown that feeds grown on-farm are more environmentally favourable than imported feeds, partly due to the lower energy requirements for transport. Full fat rapeseed (FFRS) and its co-product cold-pressed rapeseed cake (CRC) can both be locally produced, and $\mathrm{CRC}$ has been proven to be suitable for dairy cows. In both feeds, fat content limits the amount that can be supplemented in the diet, and less FFRS than CRC can be used. However, in a previous study with scenario calculations, CRC showed lower profitability than FFRS. The present study examined how milk yield and milk composition were influenced by feeding FFRS compared with CRC in organic diets and calculated the farm profitability on each occasion. The study was performed using 56 Swedish Holstein cows in different lactation stages. Diets were $100 \%$ organic, including a mixed ration (silage, grains and minerals) fed ad libitum and a restricted amount of concentrates (field beans together with either CRC or ground FFRS). There were no significant differences in milk yield and composition between the diets. However, cows fed FFRS had a higher intake of the mixed ration than cows fed CRC.
\end{abstract}

B. Johansson $(\bowtie) \cdot$ K.-I. Kumm $\cdot$ E. Nadeau

Department of Animal Environment and Health,

Swedish University of Agricultural Sciences, Box 234,

53223 Skara, Sweden

e-mail: birgitta.johansson@slu.se

M. Åkerlind

Växa Sverige, Box 288, 75105 Uppsala, Sweden
Cows fed CRC had the highest profitability in later lactation, whereas the diets were economically similar during early lactation.

Keywords Cake · Dairy cow - Organic milk production · Profitability. Rapeseed

\section{Introduction}

A basic tenet of organic production is to provide farm animals with home-grown products, and thus interest in growing and using locally produced feeds is increasing. Case studies in Sweden have shown that feeds grown on-farm have less impact on the environment than imported feeds, partly due to the lower energy requirements for transportation (Strid and Bertilsson 2010) and lower greenhouse gas emissions (Flysjo et al. 2008). It may also be economically beneficial for farmers to include more home-grown protein in dairy cow diets (Gustafsson et al. 2014). The supply of fibre and protein, especially rumen undegradable protein, is a great challenge in composing diets with large amounts of homegrown feeds. Protein in locally produced protein feeds, such as legumes and oilseeds, often contains easily degradable protein, which may lead to decreased milk yield in early lactation in comparison to feeds containing more undegradable protein (Wu and Satter 2000). In addition, overfeeding of rumen degradable protein may lead to $\mathrm{N}$ surplus and a negative effect to the environment (Jonker et al. 2002; Børsting et al. 2003). 
Oilseeds in dairy cow diets are known to improve milk fatty acid (FA) profile by increasing concentrations of nutritionally desirable FA (Chilliard and Ferlay 2004; Woods and Fearon 2009). New varieties of rapeseed with low concentrations of anti-nutritional substances are readily available (Official Statistics of Sweden 2012). Comparisons between rapeseed meal and soybean meal have shown similar production, and the question of underestimation of metabolisable protein concentration in rapeseed meal was raised (Huhtanen et al. 2011; Martineau et al. 2013). The amino acid composition in rapeseed is superior to that in soybean, which has been shown to affect the concentrations of individual amino acids in cows' blood (Rinne et al. 2012; Maxin et al. 2013), and the total essential amino acid concentration was higher in cows fed canola meal than soybean meal (Maxin et al. 2013). In particular, plasma concentration of methionine was higher and milk urea concentration lower in cows fed rapeseed compared with cows fed soybean, indicating better nitrogen $(\mathrm{N})$ use efficiency for rapeseed (Rinne et al. 2012; Maxin et al. 2013). In recent years, interest in oilseeds has increased, since (i) feeding supplementary fat diminishes methane emissions from cows (Beauchemin et al. 2009; Moate et al. 2011) and (ii) there is an increasing interest in biodiesel production from agricultural crops (Hristov et al. 2011).

Full fat rapeseed (FFRS) has been shown to have a negative influence on rumen microbes due to toxic effects when fed in excessive amounts, and its high fat content limits the amount that can be used in the diet (Sutton and Morant 1989; Jenkins 1993). Consequently, high fat diets are shown to increase the proportion of propionic acid and lower the synthesis of fatty acids in the rumen and could thereby depress milk fat content (Sutton and Morant 1989). Ground forms of full fat rapeseed have also been found to decrease dry matter (DM) intake compared to whole FFRS (Petit and Cortes 2010), but both whole and ground FFRS have inconsistent effects on milk yield, milk fat and protein contents (Beauchemin et al. 2009; Petit 2010; Lerch et al. 2012). The FFRS has a relatively slow release of fat compared with pure oils, and crushed FFRS can be fed in amounts of 1-2 kg per day with only small effects on cow metabolism (Murphy et al. 1987; Jenkins 1993). Coldpressed rapeseed cake (CRC), which is a co-product of rapeseed oil production, can be produced locally and has been proven to be suitable for dairy cows (Johansson and Nadeau 2006), although only a few studies have reported the production response of CRC (Khalili et al.
1999; Johansson and Nadeau 2006; Lerch et al. 2012). In a study with scenario calculations, CRC was found to result in a lower financial output than FFRS (Mogensen 2004).

The aims of the present study were to determine how feed intake and milk yield and composition are influenced by feeding FFRS compared with CRC in organic dairy cow diets and to calculate the financial outcome of these diets.

\section{Material and methods}

Animals, experimental design and diets

The experiment was approved by the Research Animal Ethics Committee (Swedish Board of Agriculture) and performed during the indoor period 2009-2010 on 56 Swedish Holstein cows in different lactation stages at Tingvall organic dairy farm in south-west Sweden. The start-up day of the experiment was the same for all cows, irrespective of lactation stage. The rolling herd average annual milk yield was $10,842 \mathrm{~kg}$ per cow. The cows were housed in two treatment groups in a loose-house system. Cows were paired according to their expected calving date, lactation number and previous 305-day milk yield, or breeding index for heifers, and then randomly allocated to two treatments. The diet was $100 \%$ organic, fed as a partially mixed ration (PMR) of grassclover silage and rolled grains (a mixture of one-third each of barley, wheat and oats), a small amount of a commercial compound feed (fed due to low concentration of protein in silages) and mineral feed ad libitum, supplemented with a restricted amount of protein concentrate in the form of either CRC (treatment CAKE) or ground FFRS (treatment SEED), fed in transpondercontrolled automatic feeders together with field beans in both treatments.

Cows were fed a minimum of $50 \%$ forage in the diet, calculated on a DM basis, in the first three months after calving (1-90 days in milk, DIM) and thereafter a minimum of $60 \%$ forage according to the standards for organic diets (EU 1999). Minerals and vitamins were fed according to Swedish recommendations, which are based on NRC (2001). Fat content in the total diet was used as the limiting factor for the amount of rapeseed used (approx. $5 \%$ fat). When formulating the diets, the SEED diet had a somewhat higher energy content due to the high energy concentration in the FFRS. Apart from 
that, the diets were formulated for similar nutrient composition, with special emphasis on crude protein.

Data collection

Feed sampling Grass-clover forage was ensiled in bunker silos and was stored for at least 60 days before feeding. Silage samples were taken daily and pooled to one composite sample per week for analysis of DM and one sample per silo for analysis of nutrients on a DM basis as well as water-soluble carbohydrates ( $85 \mathrm{~g}$ per $\mathrm{kg}$ DM) and fermentation characteristics (Table 1). All concentrates were sampled once a week, and the samples were pooled to one composite sample per batch for chemical analyses (Table 1).

Feed analyses and calculations The DM concentration of silage was determined at $60{ }^{\circ} \mathrm{C}$ for $24 \mathrm{~h}$ (Volden 2011), while the DM concentration of concentrates was determined at $103{ }^{\circ} \mathrm{C}$ for $24 \mathrm{~h}$ (EU 2009). Crude

Table 1 Chemical composition (mean and SD) of feeds used in the experiment: grass-clover silage $n=4$, grains $n=2$, commercial compound feed (CCF) $n=1$, field bean $n=2$, cold-pressed rapeseed cake (CRC) $n=2$, full fat rapeseed (FFRS) $n=1$; all values were protein $(\mathrm{CP})$ and neutral detergent fibre (NDF) in forages and concentrates, crude fat in concentrates and fermentation characteristics of the silages were analysed at Eurofins Laboratories Inc. (Lidköping, Sweden), as described by Johansson and Nadeau (2006). Metabolisable energy (ME) concentration of silage was calculated from in vitro rumen organic matter digestibility. Metabolisable protein, expressed as amino acids absorbed in the small intestine (AAT) and protein balance in the rumen (PBV), was calculated from standards (Madsen et al. 1995). Analyses of soluble crude protein (sCP) and indigestible NDF (iNDF; scanned by near infrared (NIR)) in silage and calculations of net energy (NE) and AAT from feeds and microbes were performed according to Volden (2011).

Other recordings Feed intake of the mixed ration was recorded at group level, while protein concentrate intake was recorded individually. It was assumed that all cows in one treatment group had the same intake of the

analysed or calculated from analyses, with the exception of ${ }^{\#}$ NorFor feed table, ${ }^{\S}$ Spörndly (2003), *Product sheet (Lantmännen Inc.), presented as $\mathrm{g} / \mathrm{kg} \mathrm{DM}$, unless otherwise stated

\begin{tabular}{|c|c|c|c|c|c|c|}
\hline & \multicolumn{6}{|l|}{ Feed } \\
\hline & Silage $^{\mathrm{g}}$ & Grains $^{\mathrm{h}}$ & $\mathrm{CCF}$ & Field bean & $\mathrm{CRC}$ & FFRS \\
\hline DM, \% & $38(9.7)$ & $85(0.1)$ & 89 & $87(1.1)$ & $90(0.1)$ & 92 \\
\hline $\mathrm{ME}^{\mathrm{a}}, \mathrm{MJ} / \mathrm{kg} \mathrm{DM}$ & $10.6(0.6)$ & $13.9(0.1)$ & $15.8^{*}$ & $14.6(0.7)$ & $15.8(0.6)$ & 22.3 \\
\hline $\mathrm{CP}$ & $135(19.6)$ & $123(8.5)$ & 338 & $288(3.5)$ & $307(9.9)$ & 253 \\
\hline $\mathrm{sCP}^{\mathrm{b}}, \mathrm{g} / \mathrm{kg} \mathrm{CP}$ & $526(68.1)$ & $124^{\#}$ & $108^{\#}$ & $691^{\#}$ & $568^{\#}$ & $334^{\#}$ \\
\hline Starch & $\mathrm{nd}^{\mathrm{i}}$ & $643(37.5)$ & $220^{*}$ & $383(87.7)$ & $10^{\S}$ & $10^{\S}$ \\
\hline Crude fat & $20^{\S}$ & $33(0.6)$ & 159 & 21 & $177(29.7)$ & 456 \\
\hline $\mathrm{AAT}^{\mathrm{c}}$ & $70(2.1)$ & $91(1.4)$ & $177^{*}$ & $95(8.5)$ & $89(3.5)$ & 74 \\
\hline $\mathrm{PBV}^{\mathrm{d}}$ & $14(18.3)$ & $-26(11.3)$ & $142^{\#}$ & $140(10.6)$ & $173(5.0)$ & 143 \\
\hline $\mathrm{NDF}^{\mathrm{e}}$ & $479(25.1)$ & $126(2.1)$ & $165^{*}$ & $219(12.7)$ & $242(0.7)$ & 184 \\
\hline $\mathrm{iNDF}^{\mathrm{f}}, \mathrm{g} / \mathrm{kg}$ NDF & $228(3.4)$ & $248^{\#}$ & $89^{\#}$ & $25^{\#}$ & $509^{\#}$ & $314^{\#}$ \\
\hline
\end{tabular}

${ }^{\mathrm{a}} \mathrm{ME}=$ metabolisable energy

${ }^{\mathrm{b}} \mathrm{SCP}=$ soluble crude protein

${ }^{\mathrm{c}} \mathrm{AAT}=$ amino acids absorbed in intestine

${ }^{\mathrm{d}} \mathrm{PBV}=$ protein balance in rumen

${ }^{\mathrm{e}} \mathrm{NDF}=$ neutral detergent fibre

${ }_{\mathrm{f}} \mathrm{NDF}=$ indigestible NDF

${ }^{\mathrm{g}}$ Fermentation characteristics (per kg DM); $\mathrm{pH}$ 4.2, 58-g lactic acid, 9.3-g acetic acid, 0.7-g propionic acid, 0.3-g butyric acid

${ }^{\mathrm{h}}$ Same proportions of barley, oats and wheat

${ }^{\mathrm{i}}$ Not determined 
mixed ration, irrespective of lactation stage. Calculations on average nutrient intake were performed by conventional calculations and according to Volden (2011). The balance of net energy (NEL) was calculated as the ratio between energy in the diet and the energy required for maintenance, lactation and body condition changes. The ratio AAT/NEL was calculated as AAT available for milk production divided by the NEL requirement for lactation. When calculating the AAT from the microbes, DM intake and amount of fermented organic matter were considered. The observed intake capacity (IC), shown as fill value (FV), depended on organic matter digestibility of the roughage, NDF level and fermentation quality and both the concentrations and amounts of starch and sugar in the total diet. The predicted IC depended on milk production, cow data (breed, DIM, body weight (BW)) and cow activity (Volden 2011).

Daily milk yield was recorded and sampled individually every second week during the first 3 months of lactation and thereafter once per month. Milk composition was analysed for fat, protein, urea and somatic cell count (SCC) by infrared technology (Eurofins Steins Laboratory Inc., Jönköping, Sweden).

Body weight was recorded monthly, and the body condition score (BCS) of the cows was determined at the same time by one trained scorer, using a visual appraisal method (Edmonson et al. 1989).

Fertility of cows was determined from the number of artificial inseminations (AI) per conception, the number of days between calving and the last $\mathrm{AI}$ and the calving interval. All veterinary inputs were recorded continuously as a measure of cow health.

\section{Profitability}

The profitability was calculated as income from milk less cost of feed for Swedish conditions (2014 figures). Quantities of milk and feed were measured in the experiment, while data on fat- and protein-adjusted milk prices were obtained from Arla Foods (2014), the price of locally produced CRC from the supplier, and the price of other feeds from production calculations by the Swedish University of Agricultural Sciences (Agriwise 2014) and the County Administration Board of Västra Götaland (2014). The cost of silage corresponded to the long-term cost of production on farms with average grass yields and machine parks well adapted to farm size in Central Sweden, and the other feed prices were set at market price. In the basic calculation, organic milk and feed prices were used. In the sensitivity analysis, prices of conventional products and $50 \%$ lower and higher milk and feed prices were used. Prices in SEK were converted into EUR at the exchange rate $1 \mathrm{SEK}=0.11 \mathrm{EUR}$ (April 2014).

Statistical analyses

Statistical analyses of variance on the 56 cows were performed using the General Linear Model (GLM) procedure of SAS (SAS 2010). Production data (milk yield and milk composition), BW, BCS and SCC were analysed as individual means for the first 3 months of lactation (5-90 DIM) and as individual means for later lactation up to 365 days of lactation. The statistical model included fixed effects of treatment and cow pair (which was used as a block). Procedure Univariate Normal Plot (SAS 2010) was used to assess normality of residuals. Values for SCC in milk were logarithmically transformed (natural logarithm), while no other transformations were made. Data presented are least square means with standard error of the mean. The back-transformed SCC values are presented for clarification. A value of $P<0.05$ was regarded as statistically significant.

\section{Results}

Feed intake and milk production

Cows fed SEED had $3.2 \mathrm{~kg}$ higher DM intake of the mixed ration than cows fed CAKE and thereby also $3.1 \mathrm{~kg}$ higher total DM intake (Table 2). The concentration of fat in the total diet was higher for SEED than for CAKE, especially in early lactation when it was $0.8 \mathrm{~g}$ higher $\mathrm{kg} \mathrm{DM}^{-1}$. The iNDF concentration was 23 and $29 \mathrm{~g} \mathrm{~kg} \mathrm{DM}^{-1}$ lower in early and later lactation in the SEED diet. The net energy balance was low $(-8 \%)$ for CAKE cows in all lactation stages, whereas SEED cows had a high energy balance in both early $(+3 \%)$ and later lactation $(+8 \%)$ (Table 3$)$. In addition, AAT/NEL was low for CAKE cows compared with the recommended level (above 15.0 for cows in lactation; Volden 2011) whereas SEED cows had AAT/NEL within the recommended level (Table 3). The observed intake capacity (shown as FV) was 10 and $5 \%$ high in early and later 
Table 2 Average feed intake in diets including either cold-pressed rapeseed cake (CAKE) or full fat rapeseed (SEED) in early (1-90 DIM ${ }^{\mathrm{a}}$ ) and later lactation (91-365 DIM)

\begin{tabular}{|c|c|c|c|c|}
\hline & \multicolumn{2}{|c|}{ CAKE } & \multicolumn{2}{|c|}{ SEED } \\
\hline & $1-90$ & $91-365$ & $1-90$ & $91-365$ \\
\hline Grass/clover silage, kg DM & 12.4 & 12.4 & 14.7 & 14.7 \\
\hline Grains $^{\mathrm{b}}, \mathrm{kg}$ feed & 4.8 & 4.8 & 5.7 & 5.7 \\
\hline $\mathrm{CCF}^{\mathrm{c}}, \mathrm{kg}$ feed & 0.32 & 0.32 & 0.35 & 0.35 \\
\hline Minerals, $\mathrm{kg}$ feed & 0.12 & 0.12 & 0.15 & 0.15 \\
\hline Lime, $\mathrm{kg}$ feed & 0.1 & 0.1 & 0.1 & 0.1 \\
\hline Intake mixed ration, $\mathrm{kg} \mathrm{DM}$ & 16.9 & 16.9 & 20.1 & 20.1 \\
\hline Rapeseed cake, $\mathrm{kg}$ feed & 2.4 & 1.5 & - & - \\
\hline Full fat rapeseed, $\mathrm{kg}$ feed & - & - & 1.3 & 0.9 \\
\hline Field bean, $\mathrm{kg}$ feed & 3.5 & 2.4 & 4.4 & 2.9 \\
\hline Total intake, $\mathrm{kg} \mathrm{DM}$ & 22.1 & 20.4 & 25.2 & 23.5 \\
\hline $\mathrm{ME}^{\mathrm{d}}, \mathrm{MJ} / \mathrm{day}$ & 267 & 245 & 310 & 280 \\
\hline $\mathrm{CP}, \mathrm{g} /$ day & 3735 & 3284 & 4082 & 3690 \\
\hline Crude fat, g/day & 88 & 69 & 121 & 92 \\
\hline $\mathrm{NDF}^{\mathrm{e}}, \mathrm{g} /$ day & 7735 & 7344 & 8870 & 8530 \\
\hline
\end{tabular}

${ }^{\text {a }}$ Days in milk

${ }^{\mathrm{b}}$ Same proportions of barley, oats and wheat

${ }^{\mathrm{c}} \mathrm{CCF}=$ commercial compound feed (Lantmännen Inc.)

${ }^{\mathrm{d}} \mathrm{ME}=$ metabolisable energy

${ }^{\mathrm{e}} \mathrm{NDF}=$ neutral detergent fibre

lactation in SEED cows compared with predicted intake, whereas it was 3 and $11 \%$ low in early and later lactation in CAKE cows (Table 3). The percentage of rumen degradable $\mathrm{CP}$ (erdCP) was 2.5 and $2.4 \%$ higher in early and later lactation in the CAKE diet than in the SEED diet, and the AAT from both the diet and microbes were highest for the SEED diet (Table 3).

There were no significant differences in milk yield, milk composition and milk urea, BW and BCS between the CAKE and SEED feed treatments (Table 4). Milk SCC did not differ between treatments. The mean SCC for 5-90 DIM was 57 and $35(\times 1,000)$ cells $/ \mathrm{mL}$ in the $\mathrm{CAKE}$ and SEED group, respectively $(\operatorname{lnSCC}=11.0$ and 10.5; SEM=0.23; $P=0.156)$. The mean $\mathrm{SCC}$ for test milkings after 90 DIM was 73 and $79(\times 1,000)$ cells $/ \mathrm{mL}$, respectively $(\operatorname{lnSCC}=11.2$ and $11.3 ; \mathrm{SEM}=0.17 ; P=$ 0.752).

\section{Reproduction and health}

There were $143 \pm 86$ and $129 \pm 88$ days from calving to last AI for cows fed the CAKE and SEED diets, respectively, and number of AI per conception was $1.54 \pm 0.72$ and $1.68 \pm 0.85$, respectively $(n=26$ and 24). The calving interval was $420 \pm 27$ and $389 \pm 51$ days for cows fed the CAKE and SEED diets, respectively ( $n=26$ and 24).

There were seven recorded disease events in the CAKE group during the study (mastitis, displaced abomasum, interdigital phlegmon (2), grass tetany, other diseases (2)) and 11 events in the SEED group (mastitis (4), interdigital phlegmon, endometritis, cystic ovary, acetonaemia, gastrointestinal nematode infection, teat injury, other diseases).

\section{Profitability}

In the basic calculation with organic milk and feed prices, cows fed the CAKE diet had the highest profitability during later lactation (10.10 and 8.62 EUR per day for CAKE and SEED, respectively). The two diets had similar profitability during early lactation (11.87 and 11.86 EUR, 
Table 3 Nutrient composition (mean and SD) in diets used in the experiment; in CAKE and SEED treatments, in early (1-90 DIM) or later lactation (91-365 DIM), calculated from feed analyses and feed intake, $n^{\mathrm{a}}=5$

\begin{tabular}{|c|c|c|c|c|}
\hline & \multicolumn{2}{|l|}{$1-90$} & \multicolumn{2}{|l|}{$91-365$} \\
\hline & CAKE & SEED & CAKE & SEED \\
\hline $\mathrm{ME}^{\mathrm{b}}, \mathrm{MJ} / \mathrm{kg} \mathrm{DM}$ & $12.1(0.3)$ & $12.3(0.4)$ & $12.0(0.4)$ & $11.9(0.4)$ \\
\hline $\mathrm{CP}, \mathrm{g} / \mathrm{kg} \mathrm{DM}$ & $169(2.6)$ & $162(4.7)$ & $161(4.2)$ & $154(4.8)$ \\
\hline Starch, g/kg DM & $174(9.3)$ & $182(10.3)$ & $171(7.4)$ & $176(8.0)$ \\
\hline Crude fat, g/kg DM & $4.0(0.1)$ & $4.8(0.3)$ & $3.4(0.1)$ & $3.9(0.2)$ \\
\hline $\mathrm{AAT}^{\mathrm{c}}, \mathrm{g} / \mathrm{MJ}$ & $6.6(0.1)$ & $6.4(0.2)$ & $6.6(0.1)$ & $6.5(0.2)$ \\
\hline $\mathrm{PBV}^{\mathrm{d}}, \mathrm{g} / \mathrm{kg} \mathrm{DM}$ & $38(3.4)$ & $32(4.0)$ & $29(3.8)$ & $23(4.0)$ \\
\hline $\mathrm{NDF}^{\mathrm{e}}, \mathrm{g} / \mathrm{kg} \mathrm{DM}$ & $350(6.5)$ & $352(3.0)$ & $360(4.5)$ & $363(3.1)$ \\
\hline $\mathrm{iNDF}^{\mathrm{f}}, \mathrm{g} / \mathrm{kg} \mathrm{NDF}$ & $234(26)$ & $211(29)$ & $232(28)$ & $203(54)$ \\
\hline NEL-balance ${ }^{\mathrm{g}}, \%$ & 92 & 103 & 92 & 108 \\
\hline AAT/NEL ${ }^{h}, g / M J$ & 12.8 & 15.0 & 13.1 & 16.5 \\
\hline Observed IC, FV & 8.15 & 9.40 & 7.79 & 9.05 \\
\hline Predicted $\mathrm{IC}^{\mathrm{j}}, \mathrm{FV}$ & 8.42 & 8.47 & 8.65 & 8.57 \\
\hline $\operatorname{erdCP}^{\mathrm{k}}, \%$ of $\mathrm{CP}$ & 78.0 & 75.5 & 77.9 & 75.5 \\
\hline $\operatorname{erdNDF}^{1}, \%$ of NDF & 54.4 & 54.4 & 55.4 & 54.9 \\
\hline $\mathrm{AAT}^{\mathrm{m}}$ feed, $\mathrm{g} / \mathrm{day}$ & 451 & 574 & 387 & 494 \\
\hline $\mathrm{AAT}^{\mathrm{n}}$ microb, $\mathrm{g} /$ day & 1419 & 1639 & 1290 & 1519 \\
\hline
\end{tabular}

${ }^{\text {a }} n$ Monthly consumption

${ }^{\mathrm{b}} \mathrm{ME}=$ metabolisable energy

${ }^{\mathrm{c}} \mathrm{AAT}=$ amino acids absorbed in intestine

${ }^{\mathrm{d}} \mathrm{PBV}=$ protein balance in rumen

${ }^{\mathrm{e}} \mathrm{NDF}=$ neutral detergent fibre

${ }^{\mathrm{f}-\mathrm{n}}$ According to Volden (2011)

${ }^{\mathrm{f}} \mathrm{NDF}=$ indigestible NDF

${ }^{\mathrm{g}} \mathrm{Net}$ energy balance, as dietary net energy in relation to the requirement

${ }^{\mathrm{h}}$ Available AAT for milk protein yield in relation to energy requirement for milk yield

${ }^{\mathrm{i}} \mathrm{IC}=$ observed intake capacity, fill value

${ }^{\mathrm{j}} \mathrm{IC}=$ Norfor predicted intake capacity

${ }^{\mathrm{k}}$ Efficient rumen degradable $\mathrm{CP}$

${ }^{1}$ Efficient rumen degradable NDF

${ }^{\mathrm{m}}$ Estimated $\mathrm{g}$ AAT from undegraded feed

${ }^{\mathrm{n}}$ Estimated g AAT from microbes

respectively), when the higher intake of the mixed ration in SEED cows was compensated for by somewhat higher milk production (Table 4).

The CAKE diet resulted in the highest profitability during later lactation in all price situations studied, including an extreme case with $50 \%$ more expensive CRC in combination with $50 \%$ cheaper FFRS, PMR and field beans. During early lactation, the two diets showed similar results in all reasonable price situations.
Similar outcome was observed when milk and feed prices for conventional production were used in calculations (data not shown).

\section{Discussion}

Both diets resulted in high milk production and similar yield and composition between the SEED and CAKE 
Table 4 Number of days in milk (mean and SD), milk yield, milk composition, BCS and BW of cows fed cold-pressed rapeseed cake (CAKE) and full fat rapeseed (SEED) diets, in early (5-90; $n=15)$ and later lactation $(91-365 ; n=27)$, expressed as least square means with standard error of means (SEM)

\begin{tabular}{|c|c|c|c|c|c|c|c|c|}
\hline & \multicolumn{4}{|c|}{ 5-90 DIM ${ }^{\mathrm{a}}$} & \multicolumn{4}{|c|}{ 91-365 DIM } \\
\hline & CAKE & SEED & SEM & $P$ & CAKE & SEED & SEM & $P$ \\
\hline Mean DIM & $53(23)$ & $51(24)$ & & & $191(76)$ & $192(75)$ & & \\
\hline Min-max DIM & $5-89$ & $5-89$ & & & $91-363$ & $91-350$ & & \\
\hline Milk yield (kg) & 37.2 & 38.3 & 1.77 & 0.69 & 31.1 & 29.9 & 0.92 & 0.37 \\
\hline Milk fat (\%) & 4.17 & 4.12 & 0.15 & 0.79 & 4.09 & 4.20 & 0.08 & 0.35 \\
\hline Milk protein $(\%)$ & 3.10 & 3.14 & 0.08 & 0.75 & 3.34 & 3.32 & 0.05 & 0.78 \\
\hline Milk urea (mmol/l) & 4.81 & 4.84 & 0.24 & 0.92 & 4.49 & 4.53 & 0.13 & 0.84 \\
\hline $\mathrm{BCS}^{\mathrm{b}}$ & 2.54 & 2.80 & 0.28 & 0.55 & 2.85 & 2.90 & 0.08 & 0.68 \\
\hline BW (kg) & 633 & 624 & 16.6 & 0.72 & 649 & 655 & 7.97 & 0.61 \\
\hline
\end{tabular}

${ }^{\text {a }}$ DIM: days in milk

${ }^{\mathrm{b}}$ Judged on a scale from 1 to 5 , where 1 is extremely lean and 5 is excessively fat (Edmonson et al. 1989), $B C S$ body condition score, $B W$ body weight, both measured on 10 cows in early lactation and 27 in later lactation

feed treatments. However, numerically higher milk yield was found for SEED cows in early lactation, consistent with the higher DM intake, but for CAKE cows in later lactation (after 90 DIM) at a lower DM intake, which partly explained the higher profitability for CAKE cows in later lactation. The CAKE and SEED diets were economically similar during early lactation. This contradicts findings in a study with scenario calculations, where growing rapeseed for CRC production gave low milk production per hectare and the lowest financial output (Mogensen 2004). The difference between studies is likely due not only to the unexpected higher feed intake by the SEED cows but also to different methods (experimental versus scenario), ways of calculations (e.g. milk yield per cow versus milk yield per hectare) and price levels.

Addition of oilseeds to lactating cow diets has been suggested to improve performance and milk fatty acid profile (Chilliard and Ferlay 2004; Woods and Fearon 2009). However, increased fat content in diets, including FFRS and CRC, has been shown to have only a slight influence on milk yield and composition (Mogensen 2004; Beauchemin et al. 2009; Hristov et al. 2011). CRC has been found to decrease milk protein content compared with diets with whole rapeseed (Lerch et al. 2012) or no rapeseed (Johansson and Nadeau 2006; Lerch et al. 2012), without influencing milk protein yield (Johansson and Nadeau 2006; Lerch et al. 2012). High fat content in dairy cow diets has been associated with decreased protein content in milk, probably due to increased milk yield (Wu and Huber 1994; Johansson and Nadeau 2006). The somewhat higher fat content in the SEED diet in the present study did not increase milk yield, and therefore there was probably no dilution of the milk protein (Wu and Huber 1994). Furthermore, lower disappearance of amino acids in the rumen has been shown from ground FFRS than from CRC (Homolka et al. 2007), which could have counteracted the higher fat content in the SEED diet.

Cows fed FFRS had a higher intake of the mixed ration than cows fed CRC, which was unexpected. Why this did not (especially in later lactation) result in higher milk yield from FFRS cows than from CRC cows is hard to elucidate but is similar to findings of an earlier long-term study where whole FFRS decreased milk yield compared to CRC (Lerch et al. 2012). As in our study, neither BW nor BCS were increased by the higher DM intake, suggesting inefficient use of energy from FFRS and the effects on yield could be explained by lower digestibility of the whole unprocessed FFRS (Lerch et al. 2012). Because of the high fat content in FFRS, it is recommended that this feed should be used in moderate amounts (maximum 1.5-2.0 kg per cow and day) in order to avoid affecting rumen microbes and rumen metabolism negatively (Murphy et al. 1987). The fat content in CRC is lower than in FFRS, and it is possible to use more CRC in the diet. Therefore, as the planned diets were balanced to have similar CP content, 
the energy content was higher in the SEED diet. Even though the protein concentration in the CAKE diet was somewhat higher compared to the SEED diet, the consumed amount of protein in the total diet was higher in the SEED cows, because of the higher DM intake by the SEED cows. Crude fat concentration in the diets consumed was higher in SEED, but not above the recommended level of $5 \%$ (NRC 2001). In addition, the seed shell in FFRS protects lipids from ruminal metabolism (Chilliard and Ferlay 2004). Thus, even though the FFRS in the present study was coarsely ground, it may have been important for rumen function as it has been shown that the release of fat is slow from crushed rapeseed which minimises negative effects of fat on rumen metabolism (Murphy et al. 1987).

The net energy balance was somewhat low for CAKE cows (NEL balance $92 \%$ in early and later lactation), which is normal for cows in early lactation. However, the SEED cows had higher intake than the CAKE cows and a positive net energy balance also in early lactation (NEL balance 103 and $108 \%$ for cows in $\leq 90$ DIM and $>90$ DIM, respectively). As mentioned, there were no differences in BW or BCS of the cows between treatments, which indicate that the low net energy balance in CAKE cows in later lactation was due to milk production. In fact, the CAKE cows produced $1 \mathrm{~kg}$ more milk per day in later lactation, in spite of the lower DM intake.

The amount of AAT available for milk production in relation to energy requirement (AAT/NEL) was also low for CAKE cows in early lactation (12.8 $\mathrm{g} / \mathrm{MJ}$ compared with the recommended minimum of $15.0 \mathrm{~g} / \mathrm{MJ}$; Volden 2011), and the estimated AAT from microbes was lower for CAKE than for the SEED diet. This was most likely because of the higher feed intake of the SEED diet, giving more efficient microbial synthesis (Volden 2011). The AAT from microbes is known to have a closer AA profile to that required by dairy cows than the AAT from feeds (NRC 2001). This may be one explanation for the numerically lower milk yield from CAKE cows than from SEED cows in early lactation. However, the SEED cows also had higher feed intake in later lactation, when milk yield was numerically higher in CAKE cows, but CAKE cows in later lactation had a higher AAT/NEL balance compared with CAKE cows in early lactation. When using diets with low levels of rumen undegradable protein, it is especially important to provide a good lysine-methionine balance (ratio of 3:1 in metabolisable protein) for increased production and cow health (Liu et al. 2013). Rapeseed is a good source of methionine in particular, e.g. in comparison with soybean (Rinne et al. 2012; Maxin et al. 2013). This is of interest if soybean, containing high levels of undegradable protein, is replaced with rapeseed in organic forage-based diets.

Furthermore, ruminal microbial protein synthesis is dependent on optimal synchronisation of energy and protein supply over time, and increasing the amount of energy in the diet results in enhanced $\mathrm{N}$ uptake by microbes (Børsting et al. 2003). Rumen degradable feed protein can then be efficiently used to build microbial protein for production, which explains the good milk production results in the present study, even though the protein in the feeds was degraded in the rumen to a high extent. In forage-based diets, nearly two-thirds of the CP reaching the small intestine is of microbial origin (Merchen and Bourquin 1994).

There were no differences in milk urea between the two isonitrogenous $( \pm 1.0 \%$ dietary $\mathrm{CP}$ concentration) diets CAKE and SEED, indicating similar $\mathrm{N}$ efficiency because diets with increasing $\mathrm{CP}$ levels decrease $\mathrm{N}$ efficiency (Marini and Van Amburgh 2003; Olmos Colmenero and Broderick 2006; Nadeau et al. 2007).

The udder health of the cows in the study was good, as shown by low SCC, and no significant difference was found between CAKE and SEED diets. Moreover, there were no major differences in other cow health or fertility parameters between the diets.

Cows fed CAKE had the highest profitability during later lactation (after 90 DIM), whereas CAKE and SEED were economically similar during early lactation. These conclusions apply for all price situations investigated. During early lactation, the higher intake of the mixed ration in SEED cows was economically compensated for by somewhat higher milk production. Based on the findings of the present study, by feeding CAKE instead of SEED during later lactation, a farmer with 100 lactating cows may improve profits by nearly 32,000 EUR per year in the basic price situation.

Other studies have reported a positive influence of including rapeseed in dairy cow diets on aspects such as methane emissions, local feed production, improved milk fatty acid profile and use of by-products of biodiesel production, making rapeseed a promising feed component to include in cows' diets. 


\section{Conclusions}

Diets containing cold-pressed rapeseed cake and full fat rapeseed both led to high milk yield and nitrogen utilisation, probably by providing rumen degradable protein simultaneously with enough energy to build microbial protein that could be utilised for milk production. Cows fed CAKE had a lower feed intake and a numerically higher milk yield than SEED cows in later lactation, which largely explained the higher profitability for CAKE cows in later lactation. The CAKE and SEED treatments were economically similar during early lactation, when the higher feed intake by the SEED cows partly was compensated for by higher milk yield. The profitability results apply for all reasonable price situations and indicate that producing CRC can be of great interest.

Acknowledgments The study was funded by the Swedish Farmers' Foundation for Agricultural Research (SLF). The authors are grateful for the possibility to carry out the experiment at the organic farm Tingvall (south-west Sweden) and would especially like to thank Albert Kuiper, farm owner, for the skilful care of the cows and practical work in the study. We also thank Lars Johansson (Department of Animal Environment and Health, Swedish University of Agricultural Sciences, Skara) for the technical assistance and Dr. Jan-Eric Englund (Department of Biosystems and Technology, Swedish University of Agricultural Sciences, Alnarp) for the statistical advice.

Open Access This article is distributed under the terms of the Creative Commons Attribution License which permits any use, distribution, and reproduction in any medium, provided the original author(s) and the source are credited.

\section{References}

Agriwise (2014) Regional enterprise budgets. Swedish University of Agricultural Sciences, Department of Economics, Uppsala, Sweden. (In Swedish). http://www.agriwise.org/

Arla Foods (2014) Räknesnurran. Beräkning av mjölkpriset baserat på Arla Foods avräkningsmodell, svenska kronor. Stockholm, Sweden. (In Swedish). http://www.arla.com/sv/ Service-links/agare/Raknesnurran

Beauchemin KA, McGinn SM, Benchaar C, Holtshausen L (2009) Crushed sunflower, flax, or canola seeds in lactating dairy cow diets: effects on methane production, rumen fermentation, and milk production. J Dairy Sci 92(5):2118-2127

Børsting CF, Kristensen T, Misciattelli L, Hvelplund T, Weisbjerg MR (2003) Reducing nitrogen surplus from dairy farms. Effects of feeding and management. Livest Prod Sci 83(23): $165-178$
Chilliard Y, Ferlay A (2004) Dietary lipids and forages interactions on cow and goat milk fatty acid composition and sensory properties. Reprod Nutr Dev 44(5):467-492

Edmonson AJ, Lean IJ, Weaver LD, Farver T, Webster G (1989) A body condition scoring chart for Holstein dairy cows. J Dairy Sci 72(1):68-78

EU (1999) Council Directive no. 1804/1999. Off J Eur Comm L222/1

EU (2009) Council Directive no. 152/2009. Off J Eur Comm L52/1

Flysjo A, Cederberg C, Strid I (2008) LCA-databas for konventionella fodermedel - miljopaverkan i samband med produktion. LCA database for conventional feed materialsenvironmental influence in relation to production. 772. The Swedish Institute for Food and Biotechnology, Swedish Dairy Association and Swedish University of Agricultural Sciences. (In Swedish)

Gustafsson AH, Swensson C, Lovang U, Persson AT, Bertilsson J, Bergsten C, Landin H, Winblad von Walter L, Henriksson M, Kronqvist C (2014) Fallstudier hos mjölkgårdar med närproducerat foder fullt ut. Report number 3, Forskningsrapporter, Växa Sverige. (In Swedish with English summary)

Homolka P, Harazim J, Trinacty J (2007) Nitrogen degradability and intestinal digestibility of rumen undegraded protein in rapeseed, rapeseed meal and extracted rapeseed meal. Czech J Anim Sci 52(11):378-386

Hristov AN, Domitrovich C, Wachter A, Cassidy T, Lee C, Shingfield KJ, Kairenius P, Davis J, Brown J (2011) Effect of replacing solvent-extracted canola meal with high-oil traditional canola, high-oleic acid canola, or high-erucic acid rapeseed meals on rumen fermentation, digestibility, milk production, and milk fatty acid composition in lactating dairy cows. J Dairy Sci 94(8): 4057-4074

Huhtanen P, Hetta M, Swensson C (2011) Evaluation of canola meal as a protein supplement for dairy cows: a review and a meta-analysis. Can J Anim Sci 91(4):529-543

Jenkins TC (1993) Lipid metabolism in the rumen. J Dairy Sci 76: 3851-3863

Johansson B, Nadeau E (2006) Performance of dairy cows fed an entirely organic diet containing cold-pressed rapeseed cake. Acta Agric Scand Anim Sci 56(3-4):128-136

Jonker JS, Kohn RA, High J (2002) Dairy herd management practices that impact nitrogen utilization efficiency. J Dairy Sci 85:1218-1226

Khalili H, Kuusela E, Saarisalo E, Suvitie M (1999) Use of rapeseed and pea grain protein supplements for organic milk production. Agric Food Sci Finl 8(3):239-252

Lerch S, Ferlay A, Pomies D, Martin B, Pires JAA, Chilliard Y (2012) Rapeseed or linseed supplements in grass-based diets: effects on dairy performance of Holstein cows over 2 consecutive lactations. J Dairy Sci 95(4):1956-1970

Liu YG, Peng HH, Schwab CG (2013) Enhancing the productivity of dairy cows using amino acids. Anim Prod Sci 53(11): 1156-1159

Madsen J, Hvelplund T, Weissbjerg MR, Bertilsson J, Olsson I, Spörndly R, Harstad O M, Volden H, Tuori M, Varvikko T, Huhtanen P \& Olafsson BL (1995) The AAT/PBV protein evaluation system for ruminants. A revision. Norwegian J Agric Sci, Suppl 19:5-37 
Marini JC, Van Amburgh ME (2003) Nitrogen metabolism and recycling in Holstein heifers. J Anim Sci 81(2):545-552

Martineau R, Ouellet DR, Lapierre H (2013) Feeding canola meal to dairy cows: a meta-analysis on lactational responses. $\mathrm{J}$ Dairy Sci 96(3):1701-1714

Maxin G, Ouellet DR, Lapierre H (2013) Effect of substitution of soybean meal by canola meal or distillers grains in dairy rations on amino acid and glucose availability. J Dairy Sci 96(12):7806-7817

Merchen NR, Bourquin LD (1994) Processes of digestion and factors influencing digestion of forage-based diets by ruminants, Forage Quality, Evaluation, and Utilization. American Society of Agronomy, Inc, Madison

Moate PJ, Williams SRO, Grainger C, Hannah MC, Ponnampalam EN, Eckard RJ (2011) Influence of cold-pressed canola, brewers grains and hominy meal as dietary supplements suitable for reducing enteric methane emissions from lactating dairy cows. Anim Feed Sci Tech 166-67:254-264

Mogensen L (2004) Organic milk production based entirely on home-grown feed. Ph.D. thesis. Page 158 pp. The Royal Veterinary and Agricultural University, Copenhagen, Denmark

Murphy M, Uden P, Palmquist DL, Wiktorsson H (1987) Rumen and total diet digestibilities in lactating cows fed diets containing full-fat rapeseed. J Dairy Sci 70(8):1572-1582

Nadeau E, Englund JE, Gustafsson AH (2007) Nitrogen efficiency of dairy cows as affected by diet and milk yield. Livest Sci 111(1-2):45-56

NRC (2001) Nutrient requirements of dairy cattle. 7th rev. edition ed. National Academy Press, Washington, DC

Official Statistics of Sweden (2012) Yearbook of agricultural statistics including food statistics. Stockholm, Sweden

Olmos Colmenero JJ, Broderick GA (2006) Effect of dietary crude protein concentration on milk production and nitrogen utilization in lactating dairy cows. J Dairy Sci 89(5):1704-1712

Petit HV (2010) Review: feed intake, milk production and milk composition of dairy cows fed flaxseed. Can J Anim Sci 90(2):115-127
Petit HV, Cortes C (2010) Milk production and composition, milk fatty acid profile, and blood composition of dairy cows fed whole or ground flaxseed in the first half of lactation. Anim Feed Sci Tech 158:36-43

Rinne M, Kuoppala K, Ahvenjarvi S, Vanhatalo A (2012) Rapeseed expeller is a better protein supplement than soybean expeller in dairy cow diets based on grass-clover silage. Pages 484-485 in Proc. The XVI International Silage Conference, Hameenlinna, Finland

SAS (2010) SAS user's guide: statistics. 9.3 ed. SAS Institute Inc, Cary

Spörndly R (2003) Fodertabeller för idisslare. Feed tables for ruminants. Report 257. Swedish University of Agricultural Sciences, Department of Animal Nutrition and Management, Uppsala, Sweden. (In Swedish)

Strid I, Bertilsson J (2010) Life cycle assessment of locally produced feed for dairy cows. Proceedings of the 1st Nordic feed science conference, Uppsala, Sweden, 2223 June 2010

Sutton JD, Morant SV (1989) A review of the potential of nutrition to modify milk-fat and protein. Livest Prod Sci 23(34):219-237

The County Administration Board (2014) Bidragskalakyler för ekologisk och konventionell produktion. Lantbruksenheten, Västra Götaland (In Swedish)

Volden H (2011) Norfor - the Nordic feed evaluation system, vol No. 130. EAAP Publication. Wageningen Academic Publishers, Wageningen, NL

Woods VB, Fearon AM (2009) Dietary sources of unsaturated fatty acids for animals and their transfer into meat, milk and eggs: a review. Livest Sci 126:1-20

Wu Z, Huber JT (1994) Relationship between dietary fat supplementation and milk protein concentration in lactation cowsa review. Livest Prod Sci 39(2):141-155

Wu Z, Satter LD (2000) Milk production during the complete lactation of dairy cows fed diets containing different amounts of protein. J Dairy Sci 83(5):1042-1051 